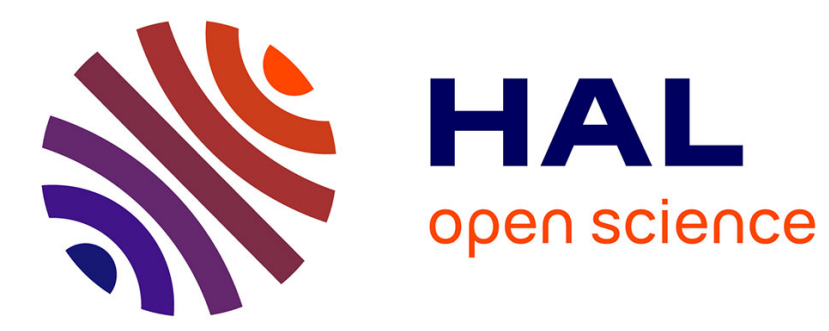

\title{
Emotional responses during repeated sprint intervals performed on level, downhill and uphill surfaces
}

Bertrand Baron, Bertrand Guilloux, Mylène Begue, Stéphane Uriac

\section{To cite this version:}

Bertrand Baron, Bertrand Guilloux, Mylène Begue, Stéphane Uriac. Emotional responses during repeated sprint intervals performed on level, downhill and uphill surfaces. Journal of Sports Sciences, 2014, 33 (5), pp.476 - 486. 10.1080/02640414.2014.947523 . hal-01388901

\section{HAL Id: hal-01388901 \\ https://hal.univ-reunion.fr/hal-01388901}

Submitted on 27 Oct 2016

HAL is a multi-disciplinary open access archive for the deposit and dissemination of scientific research documents, whether they are published or not. The documents may come from teaching and research institutions in France or abroad, or from public or private research centers.
L'archive ouverte pluridisciplinaire HAL, est destinée au dépôt et à la diffusion de documents scientifiques de niveau recherche, publiés ou non, émanant des établissements d'enseignement et de recherche français ou étrangers, des laboratoires publics ou privés. 


\title{
Emotional responses during repeated sprint intervals performed on level, downhill and uphill surfaces
}

\author{
BERTRAND BARON, BERTRAND GUILLOUX, MYLÈNE BEGUE \& STÉPHANE URIAC
}

IRISSE EA4075, Université de la Réunion, Le Tampon, France

\begin{abstract}
The purpose of this study was to test emotional responses during sprint intervals performed on a level, down and up surface. Fifty trained participants performed a maximal effort during a 60-m sprint and 10 repetitions of $60 \mathrm{~m}$ running sprints on a level, down and up surface on a 5.9\% slope. Running speeds, emotional responses and heart rate were measured. Selfselected speeds were correlated with the rating of perceived exertion, the affective balance, the desire to stop and the resources needed for the task in all conditions whereas the pleasure, the desire to continue and the capacity to realise the task were correlated with speeds only during level and uphill running. Mean values of emotional parameters were significantly different $(P<0.05)$ during running on a flat surface, downhill and uphill. When the gradient of running surface is changed, the pattern of emotional responses was just translated, i.e. most of the slope between the evolution of emotional parameters and the repetitions were not significantly different whereas $Y$-intercepts were different.

Consented effort is highly correlated with the resources needed for the task $\left(P<0.001, r^{2}=0.72\right)$. We propose that the difference in the resources needed for the task between level, downhill and uphill running $\left(F_{2,1499}=166.5, P<0.001\right.$, $\mathrm{Eta}^{2}=0.18$ ) is the most important key that explains our results.
\end{abstract}

\section{Introduction}

Pacing strategy is a critical factor determining success in sporting performance (Hettinga, De Koning, Meijer, Teunissen, \& Foster, 2007). An optimum pacing strategy can be described as one that is employed during exercise to regulate the rate of energy expenditure (de Koning, Bobbert, \& Foster, 1999; Foster, Schrager, Snyder, \& Thompson, 1994; Foster et al., 1993) in order to minimise external power losses (Hettinga, De Koning, Broersen, Van Geffen, \& Foster, 2006) and prevent premature fatigue and catastrophic failure in any peripheral physiological system before the expected end point (St Clair Gibson et al., 2006). This process has been described as an internal negotiation, which requires an estimation of the magnitude of the task remaining, the momentary power output and the remaining energetic reserves amongst other inputs (Foster et al., 2004).

According to St Clair Gibson et al. (2006), unconscious calculations continuously control emotional arousal and induce the choice of optimal intensity so that the optimum exercise intensity can be maintained until the end point. Conscious control is also identified in the mechanisms for regulating intensity (Lambert,
St Clair Gibson, \& Noakes, 2005; Noakes, St Clair Gibson, \& Lambert, 2004, 2005). Indeed, the sensation of fatigue is recognised as the conscious awareness originating from a subconscious control (St Clair Gibson et al., 2003) of the homeostatic, central governor control mechanisms (Noakes et al., 2005), and it is related to the intensity of interoceptive processes (Herbert, Pollatos, \& Schandry, 2007; Herbert, Ulbrich, \& Schandry, 2007).

Hence, the process of fatigue arousal and its regulation is complex, and a psychophysiological approach is needed (Baron, Moullan, Deruelle, \& Noakes, 2011).

However, if pacing is defined as the process of managing energy expenditure so that no factor will become limiting before the end point of exercise (Hettinga et al., 2006), when an early disturbance in physiological homeostasis occurs, it is also accompanied by a change in the affective responses (Baron et al., 2011). Ekkekakis, Hall, and Petruzzello (2005) argued that pleasure and displeasure are tied to the maintenance of homeostasis.

Hence, the physiological changes generate a barrage of interoceptive information that enters 
conscious awareness (Ekkekakis et al., 2005). Affective responses have been shown to correlate closely with indices of physiological strain, indicating a direct link between somatic afferents and the affective centres of the brain.

Moreover, the process of regulating emotions is proposed to be an effortful one that can involve using physiological resources (Lane, Wilson, Whyte, \& Shave, 2011).

In proposing the resource allocation model of selfcontrol, Beedie and Lane (2012) have retained a role for glucose, albeit as physiological mediator of the motivational and behavioural process involved in self-control.

Emotion regulation has been defined as "the process of initiating, maintaining, modulating, or changing the occurrence, intensity, or duration of internal feeling states" (Lane et al., 2011).

During performing severe-intensity exercise, what prevents the occurrence of catastrophic fatigue is the activation of a protective mechanism that precedes the failure in physiological systems and manifests itself as powerful perceptions of fatigue and displeasure (Ekkekakis et al., 2005). Affect is at the core of the life-preserving "automatic regulation system" (Ekkekakis et al., 2005).

Thus, it is proposed that during exercise the athlete must monitor not only physiological reserves but also emotional reserves so that catastrophic failure in any physiological or emotional system does not occur before the finish line (Baron et al., 2011).

It is now accepted that one function of emotion is to signal disparities between environmental conditions and personal priorities (Beedie \& Lane, 2012).

When exercise is performed until fatigue, the rising displeasure progressively reduces the conscious desire to override this control mechanism, insuring that the exercise intensity is appropriately regulated (Noakes et al., 2005).

Hence, the mental acceptance of the effort needed for the duration of exercise that remains must also be managed in the process of pacing strategy.

This is closely linked with the notion of motivation, defined as the process that determines the direction and energisation of behaviour (Gendolla \& Richter, 2010).

Indeed, individuals develop strategies that allow them to reach their goals and mobilise and monitor their behaviours in order to attain their goals (Seo, Barrett, \& Bartunek, 2004). Emotional phenomena represent central mechanisms of self-regulation that help humans deal effectively with their environments (Damasio, 1994, 1999; Seo et al., 2004). In this context, emotions are defined as the feelings of the change in visceral-afferent feedback (James, 1994).

Ekkekakis et al. (2005) consider pleasure to signify utility and displeasure to signify danger. Because low intensities are associated with pleasure, they tend to evoke approach reactions. On the other hand, high intensities tend to evoke withdrawal reactions because it is associated with displeasure (Ekkekakis et al., 2005).

Lane et al. (2011) explained that unpleasant emotional profile indicated by elevated anger, confusion, depression, fatigue and tension with reduced vigour represent emotional responses that could be triggered by a perceived failure to maintain performance goal.

Whereas numerous data have been published about the role of physiological state on pacing strategy, to the better of our knowledge the influence of emotional responses has not yet been studied in this way.

Nevertheless, the motivational intensity theory (Gendolla \& Richter, 2010) that claims that effort would be mobilised proportionally to the extent of difficulty could be one key variable of emotional regulation and pacing strategy.

Recently, we have proposed to consider not only physiological but also pleasant and unpleasant affective responses by using specific items as effort and pleasure in order to study pacing strategy (Baron et al., 2011). According to this theoretical model, the athlete must monitor the difference between the difficulty of perceived effort and the pleasure during exercise (Baron et al., 2011). In this configuration, the catastrophic failure in any physiological or emotional system does not occur before the finish line. This difference could be named as "affective balance" (AB).

We suggested that the desire to sustain high levels of effort depends on the difference between the highest level of acceptance of $\mathrm{AB}$ for the expected duration of exercise and the level of $\mathrm{AB}$ present at any moment during the exercise session.

We hypothesised that this complex brain control contributes to the regulation of the pacing strategy.

Indeed, if the level of $A B$ is near the high level of the acceptance of $\mathrm{AB}$ during exercise, the athlete must choose either comfort by reducing the exercise intensity or an increase in discomfort by maintaining the selected intensity in order to improve performance. To take into account this notion of internal conflict, the level of acceptance of $\mathrm{AB}$ could be defined as the difference between the desire to stop the exercise and the desire to continue.

St Clair Gibson and Foster (2007) have already shown that the pacing strategy is dependent on a preestablished template, i.e. that athletes develop individual pattern of pacing strategy and that this pattern is reproduced in future tasks. St Clair Gibson, Lambert, and Noakes (2001) have suggested that the motor sequences representative of the performance template are almost certainly programmed into the motor cortex from prior athletic performance. 
We suggest that a pre-established template in emotional responses would exist and influence the pacing strategies even when the nature of the task would be different, i.e. during level, downhill and uphill running.

The most important aims of the present study were to better understand the role of emotions in pacing strategies (Baron et al., 2011) and how the performance template is programmed. The logic is that the analysis of emotional regulation on different running surfaces (level, uphill and downhill) will help to determine whether emotional regulation remains the same whatever the conditions are.

\section{Methods}

\section{Participants and design}

Students (38 male and 12 female) of the Faculty of Sports Sciences gave their informed consent prior to their inclusion in the study. They trained $12.4 \pm 3.3$ hours per week in different sports. Local ethics committee has approved this work.

Participants aged $24.2 \pm 4.7$ years. Mean height and body mass values were $1.77 \pm 1.02 \mathrm{~m}$ and $67.6 \pm 6.9 \mathrm{~kg}$, respectively. This group trained for many years in different sports and for 1 year in running, including one session each week on an athletic track. Participants were taught to use the Rating of Perceived Exertion (RPE) scale (Borg, Ljunggren, \& Ceci, 1985) to monitor their exercise intensities during all these sessions. Thus, all participants were accustomed to not only quantifying their individual RPE, but also other emotional parameters (the pleasure, the desire to continue, the desire to stop, the capacity to realise the task and the resources needed for the task) when running on a flat surface.

\section{Methodology}

Level running tests (tests 1 and 4) were performed on athletic tracks of $400 \mathrm{~m}$. Uphill and downhill sprints (tests 2, 3, 5 and 6) were performed on inclined surfaces with a regular slope situated near the athletic track. Before the experiments began, a distance of $60 \mathrm{~m}$ was measured out using a decametre, whereas the lower and higher altitudes of the slope were defined using a global positioning system (GPS: FRWD W600). The altitudes of these two points and the resulting slope were measured and calculated on five different days with the same GPS to verify the results. Moreover, the accuracy of the GPS had been tested previously by comparing the change in altitude of a vertical wall measured with the GPS with that directly measured with the decametre. The slope calculated from these values was $5.9 \%$.

Before the experimental studies, participants were exposed to one training session of ten repetitions of $60 \mathrm{~m}$ performed in each condition (level, uphill and downhill running) on the same athletic track and on the same slope. In this familiarisation trial and all the subsequent tests except test 1, participants were asked to run each interval as fast as possible but were free to modulate their intensity as they chose. They were not informed of their lap times in any of the trials. All the tests began at 0900 hours and were held on the same weekday once a week for 7 consecutive weeks. Participants were asked to eat breakfast at 0700 hours and to report at the test site at 0830 hours on the experiment days. All testing was performed in warm sunny weather at an altitude of $550 \mathrm{~m}$ with an average temperature of $25.5^{\circ} \mathrm{C}$. Participants were encouraged to drink water ad libitum before and during the tests in order to avoid any potential effects of fluid loss. Seven tests were completed within a 7-week period. The tests were preceded by a 15 min jogging warm-up that included three progressive accelerations of $60 \mathrm{~m}$. Five groups of ten participants were constituted and were assigned to tests 1-6 in unalike order (group A: tests 2-3-4-5-6, group B: tests 3-5-4-6-2, group C: tests $4-5-6-3-2$, group $D$ : tests $5-3-2-6-4$, group $\mathrm{E}$ : tests $6-5-2-4-3)$.

\section{Tests 1, 2 and 3}

Participants were timed with a stopwatch whilst they produced a maximal effort during a $60-\mathrm{m}$ sprint on the level in order to determine the maximal running speed on a level (MRSL) surface. Likewise, they performed $60 \mathrm{~m}$ running bouts on the uphill and downhill inclined surface to measure maximal running speed on uphill (MRSU) and downhill surfaces (MRSD), respectively.

\section{Tests 4, 5 and 6}

Participants were instructed to run $10 \times 60 \mathrm{~m}$ on the level, uphill or downhill surfaces. Speeds were not imposed but participants were asked to perform the 10 repetitions as quickly as possible. Each $60-\mathrm{m}$ repetition was timed in order to determine the selfchosen pace when running on the level (SPL), uphill (SPU) or downhill (SPD). Between each sprint, participants rested for $4 \mathrm{~min}$.

Heart rate (HR) was continuously measured using a heart rate monitor (Polar RS800). The RPE was measured using Borg's category ratio scale (Borg et al., 1985) that consists of 11 statements ranging from 0 to 10 (from "nothing" to "maximum"). This scale was used in order to quantify all the other 
emotional parameters: that is, the pleasure $(\mathrm{P})$, the desire to continue (DC), the desire to stop (DS), the capacity to realise the task (CRT) and the resources needed for the task (R). The AB is calculated as the difference between RPE and P.

\section{Statistical analysis}

Calculations were performed using SPSS. Standard statistical methods were used for the calculation of mean and standard deviations.

One-way ANOVA was used to determine significant differences of measured variables between level, uphill and downhill running.

Normal Gaussian distribution of the data was verified by the Shapiro-Wilk's test. A two-factor ANOVA with repeated measurements was used to compare the changes in parameters at the end of each repetition.

Compound symmetry, or sphericity, was verified by the Mauchley test. Multiple comparisons were made with the Tukey HSD post hoc test when the Greenhouse-Geisser epsilon correction factor was $>0.50$, or with the Bonferroni post hoc test when the epsilon was $<0.50$.

The Pearson's coefficient was computed to test linear correlation among variables measured at the end of each repetition.

Statistical significance was set at a level of $P=0.05$ for all the analyses. $\mathrm{Eta}^{2}$, s were calculated in order to take the effect sizes into consideration.

\section{Results}

\section{Tests 1, 2 and 3 (maximal sprints)}

A statistically significant influence of the gradient of the running surface was obtained for the maximal running speed $\left(F_{2,149}=80.61, P<0.001\right.$, $\left.\mathrm{Eta}^{2}=0.52\right)$. The maximal running speed during the test of $60 \mathrm{~m}$ on a level surface was significantly higher than maximal velocity performed on an uphill slope $\left(27.01 \pm 2.4 \mathrm{~km} \cdot \mathrm{h}^{-1}\right.$ vs. $22.91 \pm 2.0 \mathrm{~km} \cdot \mathrm{h}^{-1}$; $P<0.001,\left[\mathrm{CI}_{95 \%}:-0.61\right.$ to -0.38$\left.]\right)$. Maximal running speed on level was significantly lower than the maximal velocity performed on a downhill slope $\left(22.91 \pm 2.0 \mathrm{~km} \cdot \mathrm{h}^{-1}\right.$ vs. $30.33 \pm 2.7 \mathrm{~km} \cdot \mathrm{h}^{-1}$; $P<0.001,\left[\mathrm{CI}_{95 \%}: 0.30\right.$ to 0.53$\left.]\right)$.

\section{Tests 4, 5 and 6 (repeated sprints)}

Evolution of self-selected speed in each condition of running. Self-selected speed on level and up surface decreased significantly between the first and the last repetition $\left(27.15 \pm 2.04\right.$ vs. $25.56 \pm 1.58 \mathrm{~km} \cdot \mathrm{h}^{-1}$; $22.85 \pm 1.68$ vs. $21.93 \pm 1.58 \mathrm{~km} \cdot \mathrm{h}^{-1} ; F_{9,499}=7.66$, $P<0.001,\left[\mathrm{CI}_{95 \%}:-2.46\right.$ to -1.15$], \mathrm{Eta}^{2}=0.12$ and

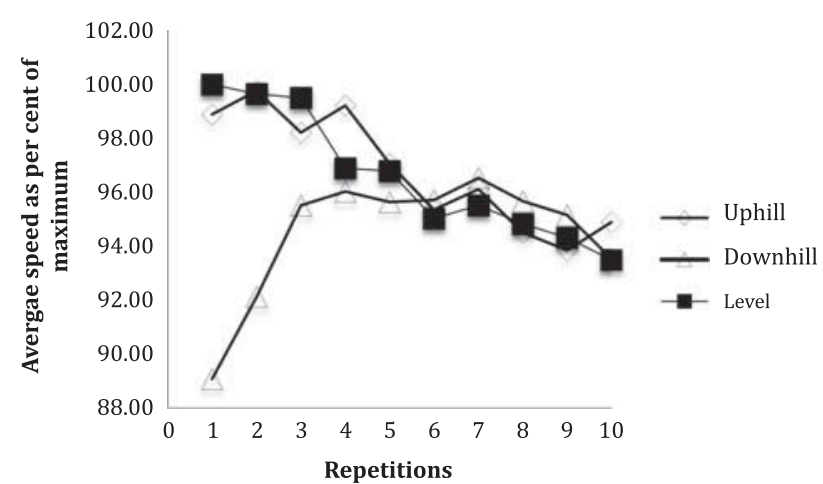

Figure 1. Average speed as a per cent of maximum during the 10 repetitions of $60 \mathrm{~m}$ performed on level, uphill and downhill surfaces.

$F_{9,499}=13.96, P<0.001,\left[\mathrm{CI}_{95 \%}-1.51\right.$ to -0.34$]$ $\mathrm{Eta}^{2}=0.19$, respectively), whereas self-selected speed during downhill significantly increased $(27.31 \pm 2.85$ vs. $28.43 \pm 1.49 \mathrm{~km} \cdot \mathrm{h}^{-1} ; F_{9,499}=6.49, P<0.001$, $\left[\mathrm{CI}_{95 \%:} 0.33\right.$ to 1.97$] \mathrm{Eta}^{2}=0.11$ ) (see Figure 1).

Influence of the gradient of the running surface on selfselected speed and emotional parameters. Mean values and standard deviation of self-selected speeds, heart rate, emotional parameters and the comparison of these variables between level, uphill and downhill repetitions are presented in Table I and Figure 2. $P$-values and confidence intervals $\left(\mathrm{CI}_{95 \%}\right)$ are presented for each analysis.

The ANOVA indicated a significant effect of the gradient of the running surface on self-selected speed $\left(F_{2}, 1499=1812\right.$, $\left.P<0.001, \mathrm{Eta}^{2}=0.71\right)$, self-selected speed expressed as per cent of maximal running speed $\left(F_{2,1499}=1664, P<0.001, \mathrm{Eta}^{2}=0.69\right), \mathrm{HR}$ $\left(F_{2,1499}=37.2, P<0.001, \mathrm{Eta}^{2}=0.04\right)$, effort $\left(F_{2,1499}=101.1, P<0.001, \mathrm{Eta}^{2}=0.12\right)$, pleasure $\left(F_{2,1499}=56.1, P<0.001, \mathrm{Eta}^{2}=0.07\right)$, $\mathrm{AB}\left(F_{2,1499}=71.4, P<0.001, \mathrm{Eta}^{2}=0.09\right)$, desire to continue $\left(F_{2,1499}=22.4, P<0.001, \mathrm{Eta}^{2}=0.03\right)$, desire to stop $\left(F_{2,1499}=64.8, P<0.001, \mathrm{Eta}^{2}=0.08\right)$, capacity to realise the task $\left(F_{2,1499}=63.3, P<0.001\right.$, $\left.\mathrm{Eta}^{2}=0.08\right)$ and the resources needed for the task $\left(F_{2}\right.$, $\left.1499=166.5, P<0.001, \mathrm{Eta}^{2}=0.18\right)$.

Important effect sizes were observed for selfselected speed, self-selected speed as per cent of maximal running speed, and effort and the resources needed for the task.

Relations between heart rate and emotional parameters. HR was correlated with emotional parameters for each condition (see Tables II, III and IV).

Relations between self-selected speed and emotional parameters. Self-selected speed was correlated with emotional parameters for each condition except for the pleasure, the desire to continue and the capacity 
Table I. Average values measured during each repetition of the tests of $10 \times 60 \mathrm{~m}$ performed on downhill, level and uphill surfaces (tests 4 , 5 and 6): self-chosen pace when running downhill, on the level and uphill (SPD, SPL and SPU); absolute and relative values in per cent of maximal running speed downhill (MRSU), on the level (MRSL) and uphill (MRSU); heart rate (HR); rating of perceived exertion (RPE); pleasure (P); affective balance (AB); desire to continue (DC); desire to stop (DS); resources needed for the task (R); and capacity to realise the task (CRT).

\begin{tabular}{|c|c|c|c|}
\hline & Uphill & Level & Downhill \\
\hline Self-chosen pace $\left(\mathrm{km} \cdot \mathrm{h}^{-1}\right)$ & $\begin{array}{l}\text { SPU: } \\
22.27 \pm 2.97 \\
\mathrm{CI}_{95 \%} \mathrm{UH}-\mathrm{L}:-4.79 \text { to }-4.28^{\star}\end{array}$ & SPL: $26.09 \pm 1.73$ & $\begin{array}{l}\text { SPD: } 28.66 \pm 2.23 \\
\mathrm{CI}_{95 \%} \mathrm{DH}-\mathrm{L}: 2.33 \text { to } 2.84^{\star} \\
\mathrm{CI}_{95 \% \mathrm{DH}-\mathrm{UH}: 6.85 \text { to } 7.39^{\star}}\end{array}$ \\
\hline $\begin{array}{l}\text { Self-chosen pace }(\% \text { of } \\
\text { maximal running speed } \\
\text { in each condition) }\end{array}$ & $\begin{array}{l}97.2 \pm 4.6 \\
\mathrm{CI}_{95 \%} \mathrm{UH}-\mathrm{L}: 0.15 \text { to } 1.21^{\star}\end{array}$ & $96.6 \pm 3.6$ & 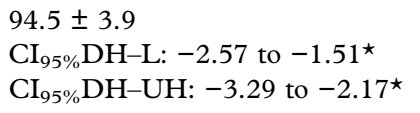 \\
\hline $\mathrm{HR}(\mathrm{bpm})$ & $\begin{array}{l}180.2 \pm 30.8 \\
\text { CI }_{95 \%} \text { UH-L: } 7.85 \text { to } 15.38^{\star}\end{array}$ & $168.6 \pm 30.6$ & 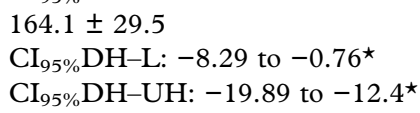 \\
\hline RPE & $\begin{array}{l}6.8 \pm 2.5 \\
\mathrm{CI}_{95 \%} \mathrm{UH}-\mathrm{L}: 0.06 \text { to } 0.63^{\star}\end{array}$ & $6.5 \pm 2.1$ & $\begin{array}{l}4.8 \pm 2.3 \\
\mathrm{CI}_{95 \%} \mathrm{DH}-\mathrm{L}:-1.91 \text { to }-1.34^{\star} \\
\mathrm{CI}_{95 \%} \mathrm{DH}-\mathrm{UH}:-2.72 \text { to }-1.68^{\star}\end{array}$ \\
\hline $\mathrm{P}$ & $\begin{array}{l}3.6 \pm 2.5 \\
\mathrm{CI}_{95 \%} \mathrm{UH}-\mathrm{L}:-1.38 \text { to }-0.81^{\star}\end{array}$ & $4.7 \pm 2.3$ & $\begin{array}{l}5.0 \pm 2.1 \\
\mathrm{CI}_{95 \%} \mathrm{DH}-\mathrm{L}: 0.12 \text { to } 0.69^{\star} \\
\mathrm{CI}_{95 \%} \mathrm{DH}-\mathrm{UH}: 1.21 \text { to } 1.78^{\star}\end{array}$ \\
\hline $\mathrm{AB}$ & $\begin{array}{l}3.1 \pm 4.8 \\
\mathrm{CI}_{95 \%} \mathrm{UH}-\mathrm{L}: 0.84 \text { to } 1.94^{\star}\end{array}$ & $1.7 \pm 4.1$ & 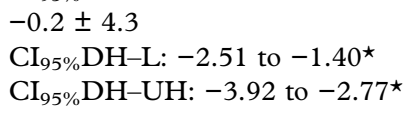 \\
\hline $\mathrm{DC}$ & $\begin{array}{l}4.5 \pm 2.7 \\
\mathrm{CI}_{95 \%} \mathrm{UH}-\mathrm{L}:-0.68 \text { to }-0.08^{\star}\end{array}$ & $4.9 \pm 2.4$ & 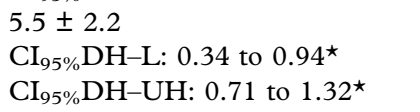 \\
\hline DS & $\begin{array}{l}6.0 \pm 2.7 \\
\mathrm{CI}_{95 \%} \mathrm{UH}-\mathrm{L}: 0.49 \text { to } 1.10^{\star}\end{array}$ & $5.2 \pm 2.5$ & $\begin{array}{l}4.2 \pm 2.3 \\
\mathrm{CI}_{95 \%} \mathrm{DH}-\mathrm{L}:-1.32 \text { to }-0.70^{\star} \\
\mathrm{CI}_{95 \%} \mathrm{DH}-\mathrm{UH}:-2.11 \text { to }-1.49^{\star}\end{array}$ \\
\hline $\mathrm{R}$ & $\begin{array}{l}7.5 \pm 1.8 \\
\mathrm{CI}_{95 \%} \mathrm{UH}-\mathrm{L}: 0.75 \text { to } 1.25^{\star}\end{array}$ & $6.5 \pm 2.0$ & $\begin{array}{l}5.1 \pm 2.3 \\
\mathrm{CI}_{95 \%} \mathrm{DH}-\mathrm{L}:-1.60 \text { to }-1.09^{\star} \\
\mathrm{CI}_{95 \%} \mathrm{DH}-\mathrm{UH}:-2.60 \text { to }-2.09^{\star}\end{array}$ \\
\hline CRT & $\begin{array}{l}4.7 \pm 2.4 \\
\mathrm{CI}_{95 \%} \mathrm{UH}-\mathrm{L}:-1.17 \text { to }-0.63^{\star}\end{array}$ & $5.6 \pm 2.3$ & $\begin{array}{l}6.2 \pm 1.9 \\
\mathrm{CI}_{95 \%} \mathrm{DH}-\mathrm{L}: 0.39 \text { to } 0.94^{\star} \\
\mathrm{CI}_{95 \%} \mathrm{DH}-\mathrm{UH}: 1.29 \text { to } 1.84^{\star}\end{array}$ \\
\hline
\end{tabular}

Notes: ${ }^{\star}$ Significant difference $(P<0.05)$.

$\mathrm{CI}_{95 \%} \mathrm{UH}-\mathrm{L}$ : Confident interval of the difference between uphill and level.

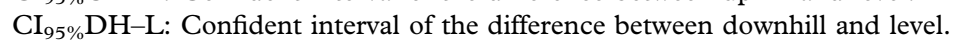

$\mathrm{CI}_{95 \%} \mathrm{UH}-\mathrm{DH}$ : Confident interval of the difference between uphill and downhill.

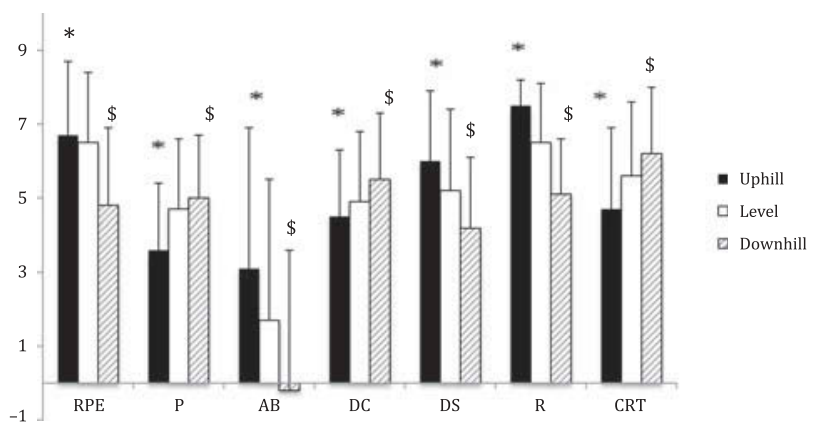

Figure 2. Average values measured during each repetition of the tests of $10 \times 60 \mathrm{~m}$ performed on downhill, level and uphill surfaces (tests 4,5 and 6): rating of perceived exertion (RPE); pleasure $(\mathrm{P})$; affective balance $(\mathrm{AB})$; desire to continue (DC); desire to stop (DS); resources needed for the task (R) and capacity to realise the task (CRT).

*: Significant difference between level and uphill.

\$: Significant difference between level and downhill.
Table II. Correlation matrix obtained between heart rate (HR) and emotional parameters during the test of $10 \times 60 \mathrm{~m}$ realised on an up surface: Rating of perceived exertion (RPE); pleasure (P); affective balance (AB); desire to continue (DC); desire to stop (DS); resources needed for the task (R) and capacity to realise the task (CRT).

\begin{tabular}{cccccccc}
\hline & RPE & P & AB & DC & DS & R & CRT \\
\hline HR & $0.75^{\star}$ & $-0.63^{\star}$ & $0.73^{\star}$ & $-0.71^{\star}$ & $0.72^{\star}$ & $0.57^{\star}$ & $-0.77^{\star}$ \\
\hline
\end{tabular}

Note: ${ }^{\star}$ Significant correlation $(P<0.05)$.

Table III. Correlation matrix obtained between heart rate (HR) and emotional parameters during the test of $10 \times 60 \mathrm{~m}$ realised on a level surface: Rating of perceived exertion (RPE); pleasure (P); affective balance (AB); desire to continue (DC); desire to stop (DS); resources needed for the task (R) and capacity to realise the task (CRT).

\begin{tabular}{cccccccc}
\hline & $\mathrm{RPE}$ & $\mathrm{P}$ & $\mathrm{AB}$ & $\mathrm{DC}$ & $\mathrm{DS}$ & $\mathrm{R}$ & $\mathrm{CRT}$ \\
\hline $\mathrm{HR}$ & $0.79^{\star}$ & $-0.66^{\star}$ & $0.77^{\star}$ & $-0.67^{\star}$ & $0.74^{\star}$ & $0.71^{\star}$ & $-0.76^{\star}$ \\
\hline
\end{tabular}

Note: ${ }^{\star}$ Significant correlation $(P<0.05)$. 
to realise the task during downhill running (see Tables V, VI, and VII).

Relations between repetitions and emotional parameters During uphill running. Perceived exertion, AB, desire to stop and resources needed for the task significantly increased between the first and the last repetition $(F \quad 9,499=76.3, P<0.001$, $\mathrm{Eta}^{2}=0.58 ; F_{9,499}=67.8, P<0.001$,

Table IV. Correlation matrix obtained between heart rate (HR) and emotional parameters during the test of $10 \times 60 \mathrm{~m}$ realised on a down surface: Rating of perceived exertion (RPE); pleasure (P); affective balance (AB); desire to continue (DC); desire to stop (DS); resources needed for the task (R) and capacity to realise the task (CRT).

\begin{tabular}{cccccccc}
\hline & $\mathrm{RPE}$ & $\mathrm{P}$ & $\mathrm{AB}$ & $\mathrm{DC}$ & $\mathrm{DS}$ & $\mathrm{R}$ & $\mathrm{CRT}$ \\
\hline $\mathrm{HR}$ & $0.67^{\star}$ & $-0.62^{\star}$ & $0.66^{\star}$ & $-0.56^{\star}$ & $0.63^{\star}$ & $0.34^{\star}$ & $-0.77^{\star}$ \\
\hline
\end{tabular}

Note: ${ }^{\star}$ Significant correlation $(P<0.05)$.

Table V. Correlation matrix obtained between SPU (expressed in per cent of MRSU) and emotional parameters during the test of $10 \times 60 \mathrm{~m}$ realised on an uphill surface: Rating of perceived exertion (RPE); pleasure (P); affective balance (AB); desire to continue (DC); desire to stop (DS); resources needed for the task (R) and capacity to realise the task (CRT).

\begin{tabular}{|c|c|c|c|c|c|c|c|}
\hline & RPE & $\mathrm{P}$ & $\mathrm{AB}$ & DC & DS & $\mathrm{R}$ & CRT \\
\hline SPU & $-0.49^{\star}$ & $0.48^{\star}$ & $-0.50^{\star}$ & $0.52^{\star}$ & $-0.48^{\star}$ & $-0.41^{\star}$ & $0.55^{\star}$ \\
\hline
\end{tabular}

Note: ${ }^{\star}$ Significant correlation $(P<0.05)$.

Table VI. Correlation matrix obtained between SPL (expressed in per cent of MRSL) and emotional parameters during the test of $10 \times 60 \mathrm{~m}$ realised on a level surface: Rating of perceived exertion (RPE); pleasure (P); affective balance (AB); desire to continue (DC); desire to stop (DS); resources needed for the task (R) and capacity to realise the task (CRT).

\begin{tabular}{cccccccc}
\hline $\mathrm{RPE}$ & $\mathrm{P}$ & $\mathrm{AB}$ & $\mathrm{DC}$ & $\mathrm{DS}$ & $\mathrm{R}$ & $\mathrm{CRT}$ \\
\hline $\mathrm{SPL}$ & $-0.69^{\star}$ & $0.59^{\star}$ & $-0.68^{\star}$ & $0.62^{\star}$ & $-0.71^{\star}$ & $-0.73^{\star}$ & $0.56^{\star}$ \\
\hline
\end{tabular}

Note: ${ }^{\star}$ Significant correlation $(P<0.05)$.

Table VII. Correlation matrix obtained between SPD (expressed in per cent of MRSD) and emotional parameters during the test of $10 \times 60 \mathrm{~m}$ realised on a downhill surface: Rating of perceived exertion (RPE); pleasure (P); affective balance (AB); desire to continue (DC); desire to stop (DS); resources needed for the task (R) and capacity to realise the task (CRT).

\begin{tabular}{cccccccc}
\hline & $\mathrm{RPE}$ & $\mathrm{P}$ & $\mathrm{AB}$ & $\mathrm{DC}$ & $\mathrm{DS}$ & $\mathrm{R}$ & $\mathrm{CRT}$ \\
\hline $\mathrm{SPD}$ & $0.26^{\star}$ & -0.20 & $0.24^{\star}$ & -0.20 & $0.24^{\star}$ & $0.35^{\star}$ & -0.18 \\
\hline
\end{tabular}

Note: ${ }^{\star}$ Significant correlation $(P<0.05)$.
Table VIII. Average values of the first and the last repetition of each emotional parameter during uphill repetitions: Rating of perceived exertion (RPE), pleasure (P), affective balance (AB), desire to continue (DC), desire to stop (DS), resources needed for the task (R) and capacity to realise the task (CRT).

\begin{tabular}{lrl}
\hline Parameters & $\begin{array}{c}\text { Values of the } \\
\text { first repetition }\end{array}$ & Values of the last repetition \\
\hline $\mathrm{RPE}$ & $3.4 \pm 1.9$ & $9.1 \pm 0.9^{\star} \mathrm{CI}_{95 \%}: 5.09$ to 6.24 \\
$\mathrm{AB}$ & $-3.0 \pm 4.2$ & $7.9 \pm 1.8^{\star} \mathrm{CI}_{95 \%}: 9.61$ to 12.17 \\
$\mathrm{DS}$ & $3.0 \pm 2.5$ & $8.8 \pm 1.3^{\star} \mathrm{CI}_{95 \%}: 4.99$ to 6.57 \\
$\mathrm{R}$ & $6.0 \pm 2.3$ & $8.2 \pm 2.3^{\star} \mathrm{CI}_{95 \%}: 1.31$ to 3.14 \\
$\mathrm{P}$ & $6.4 \pm 2.6$ & $1.2 \pm 1.0^{\star} \mathrm{CI}_{95 \%}:-6.00$ to -4.44 \\
$\mathrm{DC}$ & $7.4 \pm 2.3$ & $1.7 \pm 1.3^{\star} \mathrm{CI}_{95 \%}:-6.51$ to -5.05 \\
$\mathrm{CRT}$ & $7.7 \pm 1.2$ & $1.4 \pm 1.2^{\star} \mathrm{CI}_{95 \%}:-6.70$ to -5.75 \\
\hline
\end{tabular}

Notes: ${ }^{\star}$ Main effect of repetitions.

$\mathrm{CI}_{95 \%}$ : Confident interval of the difference between first and last repetitions.

$\mathrm{Eta}^{2}=0.55 ; \quad F_{9,499}=58.6, \quad P<0.001$, $\mathrm{Eta}^{2}=0.52 ; F_{9}, 499=11.3, P<0.001$, $\mathrm{Eta}^{2}=0.17$, respectively), whereas pleasure, desire to continue and capacity to realise the task significantly decreased $\left(F_{9,499}=52.15, P<0.001\right.$, $\mathrm{Eta}^{2}=0.49 ; \quad F_{9}, 499=39.45, P<0.001$, $\mathrm{Eta}^{2}=0.42 ; \quad F 9,499=197.9, P<0.001$, $\mathrm{Eta}^{2}=0.78$, respectively, see Tables VIII). Effect sizes were important for all these parameters.

During level running. Likewise, Perceived exertion, $\mathrm{AB}$, desire to stop and resources needed for the task significantly increased between the first and the last repetition $\left(F_{9,499}=184.1, P<0.001, \mathrm{Eta}^{2}=0.77 ; \mathrm{F}\right.$ $9,499=188.2, P<0.001, \mathrm{Eta}^{2}=0.78 ; F_{9,499}=157.6$, $P<0.001, \mathrm{Eta}^{2}=0.74 ; F_{9,499}=87.4, P<0.001$, $\mathrm{Eta}^{2}=0.62$, respectively), whereas pleasure, desire to continue and capacity to realise the task significantly decreased during level running $\left(F_{9,499}=90.6\right.$, $P<0.001, \mathrm{Eta}^{2}=0.62 ; F_{9,499}=83.5, P<0.001$, $\mathrm{Eta}^{2}=0.6 ; F_{9,499}=153.6, P<0.001, \mathrm{Eta}^{2}=0.74$,

Table IX. Average values of the first and the last repetition of each emotional parameter during level repetitions: Rating of perceived exertion (RPE), pleasure (P), affective balance (AB), desire to continue (DC), desire to stop (DS), resources needed for the task (R) and capacity to realise the task (CRT).

\begin{tabular}{lrl}
\hline Parameters & $\begin{array}{c}\text { Values of the } \\
\text { first repetition }\end{array}$ & Values of the last repetition \\
\hline RPE & $3.4 \pm 1.4$ & $9.1 \pm 0.9^{\star} \mathrm{CI}_{95 \%}: 5.18$ to 6.15 \\
$\mathrm{AB}$ & $-3.4 \pm 1.8$ & $7.0 \pm 2.4^{\star} \mathrm{CI}_{95 \%}: 9.60$ to 11.29 \\
$\mathrm{DS}$ & $2.5 \pm 0.8$ & $8.9 \pm 1.3^{\star} \mathrm{CI}_{95 \%}: 5.90$ to 6.76 \\
$\mathrm{R}$ & $3.9 \pm 1.1$ & $8.8 \pm 1.3^{\star} \mathrm{CI}_{95 \%}: 4.39$ to 5.38 \\
$\mathrm{P}$ & $6.9 \pm 1.5$ & $2.1 \pm 1.5^{\star} \mathrm{CI}_{95 \%}:-5.37$ to -4.19 \\
$\mathrm{DC}$ & $7.4 \pm 1.7$ & $1.5 \pm 1.6^{\star} \mathrm{CI}_{95 \%}:-6.54$ to -5.24 \\
CRT & $8.2 \pm 1.3$ & $2.7 \pm 1.5^{\star} \mathrm{CI}_{95 \%}:-6.11$ to -5.01 \\
\hline
\end{tabular}

Notes: ${ }^{\star}$ Main effect of repetitions.

$\mathrm{CI}_{95 \%}$ : Confident interval of the difference between first and last repetitions. 
Table X. Average values of the first and the last repetition of each emotional parameter during downhill repetitions: Rating of perceived exertion (RPE), pleasure $(\mathrm{P})$, affective balance $(\mathrm{AB})$, desire to continue (DC), desire to stop (DS), resources needed for the task (R) and capacity to realise the task (CRT).

\begin{tabular}{lrl}
\hline Parameters & $\begin{array}{c}\text { Values of the } \\
\text { first repetition }\end{array}$ & Values of the last repetition \\
\hline $\mathrm{RPE}$ & $1.8 \pm 1.2$ & $8.1 \pm 1.1^{\star} \mathrm{CI}_{95 \%}: 5.89$ to 6.78 \\
$\mathrm{AB}$ & $-5.3 \pm 2.7$ & $5.9 \pm 2.1^{\star} \mathrm{CI}_{95 \%}: 10.26$ to 12.18 \\
$\mathrm{DS}$ & $1.3 \pm 1.5$ & $7.2 \pm 1.2^{\star} \mathrm{CI}_{95 \%}: 5.35$ to 6.42 \\
$\mathrm{R}$ & $2.8 \pm 2.0$ & $7.0 \pm 2.2^{\star} \mathrm{CI}_{95 \%}: 3.27$ to 4.96 \\
$\mathrm{P}$ & $7.1 \pm 2.3$ & $2.2 \pm 1.3^{\star} \mathrm{CI}_{95 \%}:-5.62$ to -4.16 \\
$\mathrm{DC}$ & $8.0 \pm 1.3$ & $2.6 \pm 1.0^{\star} \mathrm{CI}_{95 \%}:-5.89$ to -5.00 \\
$\mathrm{CRT}$ & $8.8 \pm 1.2$ & $3.3 \pm 1.1^{\star} \mathrm{CI}_{95 \%}:-5.90$ to -4.99 \\
\hline
\end{tabular}

Notes: ${ }^{\star}$ Main effect of repetitions.

$\mathrm{CI}_{95 \%}$ : Confident interval of the difference between first and last repetitions.

respectively, see Table IX). Effect sizes were important for all these parameters.

During downhill running. Perceived exertion, AB, desire to stop and resources needed for the task significantly increased between the first and the last repetition $\left(F_{9,499}=157.4, P<0.001, \mathrm{Eta}^{2}=0.74\right.$; $F_{9,499}=137.9, P<0.001, \mathrm{Eta}^{2}=0.72$; $F_{9,} 499=109.4, P<0.001, \mathrm{Eta}^{2}=0.67$; $F_{9,499}=38.5, P<0.001, \mathrm{Eta}^{2}=0.42$, respectively), whereas pleasure, desire to continue and capacity to realise the task significantly decreased during downhill running $\left(F_{9,499}=76,7, P<0.001, \mathrm{Eta}^{2}=0.58 ; F\right.$ $9,499=102.7, P<0.001, \mathrm{Eta}^{2}=0.65 ; F_{9,499}=214.6$, $P<0.001, \mathrm{Eta}^{2}=0.79$, respectively, see Table X). Effect sizes were important for all these parameters.

Table XI. Correlation matrix obtained between repetitions and emotional parameters during the test of $10 \times 60 \mathrm{~m}$ realised on an uphill surface: Rating of perceived exertion (RPE), pleasure $(\mathrm{P})$, affective balance $(\mathrm{AB})$, desire to continue (DC), desire to stop (DS), resources needed for the task (R) and capacity to realise the task (CRT).

\begin{tabular}{cccccccc}
\hline RPE & $P$ & AB & DC & DS & R & CRT \\
\hline Repetitions & $0.74^{\star}$ & $-0.67^{\star}$ & $0.72^{\star}$ & $-0.62^{\star}$ & $0.68^{\star}$ & $0.38^{\star}$ & $-0.88^{\star}$ \\
\hline
\end{tabular}

Note: ${ }^{\star}$ Significant correlation $(P<0.05)$.

Table XII. Correlation matrix obtained between repetitions and emotional parameters during the test of $10 \times 60 \mathrm{~m}$ realised on a level surface: Rating of perceived exertion (RPE); pleasure (P), affective balance $(\mathrm{AB})$, desire to continue (DC), desire to stop (DS), resources needed for the task (R) and capacity to realise the task (CRT).

\begin{tabular}{cccccccc}
\hline RPE & P & AB & DC & DS & R & CRT \\
\hline Repetitions & $0.87^{\star}$ & $-0.76^{\star}$ & $0.89^{\star}$ & $-0.74^{\star}$ & $0.85^{\star}$ & $0.76^{\star}$ & $-0.87^{\star}$ \\
\hline
\end{tabular}

Note: ${ }^{\star}$ Significant correlation $(P<0.05)$.
Table XIII. Correlation matrix obtained between repetitions and emotional parameters during the test of $10 \times 60 \mathrm{~m}$ realised on a downhill surface: Rating of perceived exertion (RPE), pleasure $(\mathrm{P})$, affective balance $(\mathrm{AB})$, desire to continue (DC), desire to stop (DS), resources needed for the task (R) and capacity to realise the task (CRT).

\begin{tabular}{cccccccc}
\hline & $\mathrm{RPE}$ & $\mathrm{P}$ & $\mathrm{AB}$ & $\mathrm{DC}$ & $\mathrm{DS}$ & $\mathrm{R}$ & $\mathrm{CRT}$ \\
\hline Repetitions & $0.85^{\star}$ & $-0.74^{\star}$ & $0.83^{\star}$ & $-0.78^{\star}$ & $0.80^{\star}$ & $0.63^{\star}$ & $-0.91^{\star}$ \\
\hline
\end{tabular}

Note: ${ }^{\star}$ Significant correlation $(P<0.05)$.

Each parameter was correlated with repetitions in each condition of running (see Tables XI, XII and XIII).

An ANOVA was used to determine the effect of the gradient on the slope between repetitions and the evolution of each parameter (see Table XIV).

Results show that there is no effect for the gradient of the running surface on the slope of effort $\left(F_{2,1499}=1.55, P=0.216, \mathrm{Eta}^{2}=0.02\right)$, pleasure $\left(F_{2,1499}=0.36, P=0.699, \mathrm{Eta}^{2}=0.0049\right), \mathrm{AB}$ $\left(F_{2,1499}=0.046, P=0.955, \mathrm{Eta}^{2}=0.0006\right)$, desire to continue $\left(F_{2}, \quad 1499=0.37, P=0.69\right.$, $\left.\mathrm{Eta}^{2}=0.005\right)$, desire to stop $\left(F_{2,1499}=2.05\right.$, $\left.P=0.132, \mathrm{Eta}^{2}=0.0047\right)$, whereas a main effect was observed on the slope of the capacity to realise the task $\left(F_{2,1499}=5.6, P=0.004, \mathrm{Eta}^{2}=0.05\right)$, and on the slope of the resources needed for the task $\left(F_{2,}{ }_{1499}=3.2, P=0.044, \mathrm{Eta}^{2}=0.051\right)$. Nevertheless, effect sizes were low for these two parameters.

Likewise, an ANOVA was used to determine the effect of the gradient of the running surface on the $Y$-intercept between the repetitions and the evolution of each parameter (see Table XV).

Results show that there is a significant effect for the gradient of the running surface on the $Y$-intercept of effort $\left(F_{2,1499}=125.1, P<0.001\right.$, $\left.\mathrm{Eta}^{2}=0.25\right)$, pleasure $\left(F_{2,1499}=6.29, P=0.002\right.$, $\left.\mathrm{Eta}^{2}=0.078\right), \mathrm{AB}\left(F_{2,1499}=13.09, P<0.001\right.$, $\left.\mathrm{Eta}^{2}=0.15\right)$, desire to continue $\left(F_{2,1499}=3.3\right.$, $\left.P=0.04, \mathrm{Eta}^{2}=0.047\right)$, desire to stop $\left(F_{2}\right.$, $\left.1499=12.18, P<0.001, \mathrm{Eta}^{2}=0.1557\right)$, the capacity to realise the task $\left(F_{2,1499}=8.23, P<0.001\right.$, $\left.\mathrm{Eta}^{2}=0.11\right)$, the resources needed for the task $(F$ $\left.2,1499=13.66, P<0.001, \mathrm{Eta}^{2}=0.19\right)$. Important effect sizes were observed for all parameters except for pleasure and desire to continue.

\section{Discussion}

The first finding of this study was that when expressed as a per cent of maximal running speed on each condition, the relative average speed was lower during repetitive downhill sprints than during sprints on the flat surface $(-2.2 \%$, approximately), whereas it was slightly higher during uphill sprints 
Table XIV. Average values of slope measured between the repetition and the evolution of emotional parameters during the tests of $10 \times 60 \mathrm{~m}$ performed on downhill, level and uphill surfaces (tests 4,5 and 6): Rating of perceived exertion (RPE), pleasure (P), affective balance (AB), desire to continue (DC), desire to stop (DS), resources needed for the task $(\mathrm{R})$ and capacity to realise the task (CRT).

\begin{tabular}{|c|c|c|c|}
\hline & Uphill & Level & Downhill \\
\hline RPE & $\begin{array}{l}0.66 \pm 0.17 \\
\mathrm{CI}_{95 \%} \mathrm{UH}-\mathrm{L}:-0.04 \text { to } 0.10\end{array}$ & $0.64 \pm 0.15$ & $\begin{array}{l}0.69 \pm 0.17 \\
\mathrm{CI}_{95 \% \mathrm{DH}-\mathrm{L}:-0.01 \text { to } 0.13} \\
\mathrm{CI}_{95 \%} \mathrm{DH}-\mathrm{UH}:-0.04 \text { to } 0.10\end{array}$ \\
\hline $\mathrm{P}$ & $\begin{array}{l}-0.60 \pm 0.24 \\
\mathrm{CI}_{95 \%} \mathrm{UH}-\mathrm{L}:-0.09 \text { to } 0.11\end{array}$ & $-0.61 \pm 0.28$ & $\begin{array}{l}-0.57 \pm 0.20 \\
\mathrm{CI}_{95 \%} \mathrm{DH}-\mathrm{L}:-0.06 \text { to } 0.14 \\
\mathrm{CI}_{95 \%} \mathrm{DH}-\mathrm{UH}:-0.13 \text { to } 0.27\end{array}$ \\
\hline $\mathrm{AB}$ & $\begin{array}{l}1.26 \pm 0.42 \\
\mathrm{CI}_{95 \%} \mathrm{UH}-\mathrm{L}:-0.13 \text { to } 0.16\end{array}$ & $1.24 \pm 0.38$ & $\begin{array}{l}1.26 \pm 0.29 \\
\mathrm{CI}_{95 \% \mathrm{DH}-\mathrm{L}:-0.12 \text { to } 0.16} \\
\mathrm{CI}_{95 \% \mathrm{DH}-\mathrm{UH}:-0.14 \text { to } 0.15}\end{array}$ \\
\hline $\mathrm{DC}$ & $\begin{array}{l}-0.65 \pm 0.15 \\
\mathrm{CI}_{95 \%} \mathrm{UH}-\mathrm{L}:-0.06 \text { to } 0.09\end{array}$ & $-0.66 \pm 0.24$ & $\begin{array}{l}-0.63 \pm 0.12 \\
\mathrm{CI}_{95 \% \mathrm{DH}-\mathrm{L}:-0.04 \text { to } 0.11} \\
\mathrm{CI}_{95 \% \mathrm{DH}-\mathrm{UH}:-0.04 \text { to } 0.08}\end{array}$ \\
\hline DS & $\begin{array}{l}0.69 \pm 0.18 \\
\mathrm{CI}_{95 \%} \mathrm{UH}-\mathrm{L}:-0.17 \text { to } 0.01\end{array}$ & $0.76 \pm 0.26$ & $\begin{array}{l}0.69 \pm 0.17 \\
\mathrm{CI}_{95 \%} \mathrm{DH}-\mathrm{L}:-0.17 \text { to } 0.01 \\
\mathrm{CI}_{95 \%} \mathrm{DH}-\mathrm{UH}:-0.08 \text { to } 0.07\end{array}$ \\
\hline $\mathrm{R}$ & $\begin{array}{l}0.50 \pm 0.16 \\
\mathrm{CI}_{95 \%} \mathrm{UH}-\mathrm{L}:-0.18 \text { to }-0.03^{\star}\end{array}$ & $0.61 \pm 0.15$ & $\begin{array}{l}0.51 \pm 0.17 \\
\mathrm{CI}_{95 \%} \mathrm{DH}-\mathrm{L}:-0.17 \text { to }-0.02^{\star} \\
\mathrm{CI}_{95 \%} \mathrm{DH}-\mathrm{UH}:-0.06 \text { to } 0.09\end{array}$ \\
\hline CRT & $\begin{array}{l}-0.77 \pm 0.06 \\
\mathrm{CI}_{95 \%} \mathrm{UH}-\mathrm{L}:-0.13 \text { to } 0.03\end{array}$ & $-0.72 \pm 0.27$ & $\begin{array}{l}-0.61 \pm 0.19 \\
\mathrm{CI}_{95 \%} \mathrm{DH}-\mathrm{L}: 0.02 \text { to } 0.19^{\star} \\
\mathrm{CI}_{95 \%} \mathrm{DH}-\mathrm{UH}: 0.09 \text { to } 0.22^{\star}\end{array}$ \\
\hline
\end{tabular}

Notes: ${ }^{\star}$ Significant difference $(P<0.05)$.

$\mathrm{CI}_{95 \%} \mathrm{UH}-\mathrm{L}$ : Confident interval of the difference between uphill and level.

$\mathrm{CI}_{95 \%}$ DH-L: Confident interval of the difference between downhill and level.

$\mathrm{CI}_{95 \%} \mathrm{UH}-\mathrm{DH}$ : Confident interval of the difference between uphill and downhill.

Table XV. Average values of $Y$-intercept measured between the repetition and the evolution of emotional parameters during the tests of $10 \times 60 \mathrm{~m}$ performed on downhill, level and uphill surfaces (tests 4,5 and 6 ): Rating of perceived exertion (RPE), pleasure (P), affective balance (AB), desire to continue (DC), desire to stop (DS), resources needed for the task (R) and capacity to realise the task (CRT).

\begin{tabular}{|c|c|c|c|}
\hline & Uphill & Level & Downhill \\
\hline RPE & $\begin{array}{l}3.07 \pm 2.36 \\
\mathrm{CI}_{95 \%} \mathrm{UH}-\mathrm{L}:-0.62 \text { to } 0.71\end{array}$ & $3.03 \pm 1.13$ & $\begin{array}{l}0.10 \pm 1.24 \\
\mathrm{CI}_{95 \%} \mathrm{DH}-\mathrm{L}:-2.69 \text { to }-1.37^{\star} \\
\mathrm{CI}_{95 \%} \mathrm{DH}-\mathrm{UH}:-2.82 \text { to }-1.33^{\star}\end{array}$ \\
\hline $\mathrm{P}$ & $\begin{array}{l}6.88 \pm 2.74 \\
\mathrm{CI}_{95 \%} \mathrm{UH}-\mathrm{L}:-2.06 \text { to }-0.43^{\star}\end{array}$ & $8.13 \pm 1.57$ & $\begin{array}{l}8.16 \pm 1.65 \\
\mathrm{CI}_{95 \%} \mathrm{DH}-\mathrm{L}:-0.78 \text { to } 0.85 \\
\mathrm{CI}_{95 \%} \mathrm{DH}-\mathrm{UH}: 0.39 \text { to } 2.18^{\star}\end{array}$ \\
\hline $\mathrm{AB}$ & $\begin{array}{l}-4.00 \pm 4.82 \\
\mathrm{CI}_{95 \%} \mathrm{UH}-\mathrm{L}:-0.02 \text { to } 2.60\end{array}$ & $-5.08 \pm 1.75$ & $\begin{array}{l}-7.17 \pm 2.28 \\
\mathrm{CI}_{95 \%} \mathrm{DH}-\mathrm{L}:-3.37 \text { to }-0.76^{\star} \\
\mathrm{CI}_{95 \%} \mathrm{DH}-\mathrm{UH}:-4.89 \text { to }-1.82^{\star}\end{array}$ \\
\hline DC & $\begin{array}{l}7.80 \pm 2.60 \\
\mathrm{CI}_{95 \%} \mathrm{UH}-\mathrm{L}:-1.17 \text { to } 0.35\end{array}$ & $8.21 \pm 1.29$ & 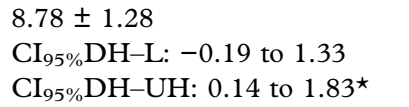 \\
\hline DS & $\begin{array}{l}2.46 \pm 2.49 \\
\mathrm{CI}_{95 \%} \mathrm{UH}-\mathrm{L}: 0.47 \text { to } 1.98^{\star}\end{array}$ & $1.23 \pm 1.05$ & $\begin{array}{l}0.60 \pm 1.60 \\
\mathrm{CI}_{95 \%} \mathrm{DH}-\mathrm{L}:-1.39 \text { to } 0.12 \\
\mathrm{CI}_{95 \%} \mathrm{DH}-\mathrm{UH}:-2.74 \text { to }-0.98^{\star}\end{array}$ \\
\hline $\mathrm{R}$ & $\begin{array}{l}4.82 \pm 1.49 \\
\mathrm{CI}_{95 \%} \mathrm{UH}-\mathrm{L}: 0.51 \text { to } 1.95^{\star}\end{array}$ & $3.59 \pm 1.32$ & $\begin{array}{l}2.96 \pm 1.97 \\
\mathrm{CI}_{95 \%} \mathrm{DH}-\mathrm{L}:-1.34 \text { to } 0.08 \\
\mathrm{CI}_{95 \%} \mathrm{DH}-\mathrm{UH}:-2.63 \text { to }-1.08^{\star}\end{array}$ \\
\hline CRT & $\begin{array}{l}8.70 \pm 1.03 \\
\mathrm{CI}_{95 \%} \mathrm{UH}-\mathrm{L}:-1.20 \text { to }-0.19^{\star}\end{array}$ & $9.39 \pm 1.51$ & $\begin{array}{l}9.71 \pm 1.48 \\
\mathrm{CI}_{95 \% \mathrm{DH}-\mathrm{L}:-0.18 \text { to } 0.83} \\
\mathrm{CI}_{95 \%} \mathrm{DH}-\mathrm{UH}: 0.54 \text { to } 1.49^{\star}\end{array}$ \\
\hline
\end{tabular}

Notes: ${ }^{\star}$ Significant difference $(P<0.05)$.

$\mathrm{CI}_{95 \%} \mathrm{UH}-\mathrm{L}$ : Confident interval of the difference between uphill and level.

$\mathrm{CI}_{95 \%} \mathrm{DH}-\mathrm{L}$ : Confident interval of the difference between downhill and level.

$\mathrm{CI}_{95 \%} \mathrm{UH}-\mathrm{DH}$ : Confident interval of the difference between uphill and downhill. 
(+0.6\%, approximately). Statistical analyses show important effect sizes. This is in accordance with our previous results (Baron et al., 2009). Hence, the more was the gradient of the running surface, the higher was the self-selected speed when expressed as per cent of maximal running speed, or the more were the eccentric component; the lower was the self-selected speed when expressed as per cent of maximal running speed.

This result is in accordance with the hypothesis that claims that during downhill running the pace is regulated, not exclusively to conserve physiological homeostasis (Baron, Noakes, Dekerle, Moullan, Robin, Matran et al., 2008; Lambert et al., 2005; Noakes et al., 2005) and energetic reserve (Foster, De Koning, Hettinga, Lampen, La Clair, Dodge, et al., 2003), but also to regulate the increased muscular strain induced by eccentric action, presumably in order to prevent severe musculoskeletal damage or disruption (Mizrahi, Verbitsky, \& Isakov, 2000; Peake, Nosaka, \& Suzuki, 2005).

But the most important question is: "how this process works?"

Two mechanisms could be spontaneously proposed: The first is that when physiological damage is imposed, the importance of the non-conscious part of control is higher than the conscious part or is reinforced in order to preserve the organism (Baron et al., 2009). It corresponds to physiological and neurophysiological mechanisms in which emotional responses do not influence pacing strategy. We have previously suggested that emotional arousal likely takes longer to develop than do the processes involved in physiological control (Baron et al., 2011). We proposed that a non-conscious physiological process is most effective when rapid adjustments in power output are needed during short events. We supposed that a conscious process reinforces subconscious controls only during more prolonged exercise.

But the results of the present study are in accordance with a second mechanism of control. Hence, as explained by Gendolla and Richter (2010), the intensity of effort is determined by the difficulty of behaviour because effort is mobilised to overcome obstacles. The organism does not mobilise more resources than necessary. In motivational intensity theory, one key variable that determines resource mobilisation is subjective task difficulty. Hence, effort would be mobilised proportionally to the extent of difficulty. Results of this study show that effort is effectively highly correlated with the resources needed for the task $\left(P<0.001, r^{2}=0.72\right)$.

Our results show that during downhill running the resources needed for the task were lower than that required during level running whereas these parameters were higher during uphill condition with important effect sizes. Hence, it supports the motivational intensity theory and the notion of motivational intelligence (Gendolla \& Richter, 2010) that explains that runners mobilise more resources during uphill than during level and downhill repetitions.

The results of the present study highlight that a conscious part of control is effective during intermittent exercise composed by short repetitions.

Self-selected speed significantly decreased during level and uphill running. This strategy corresponds to the so-called "all-out" approach frequently observed during short events (St Clair Gibson et al., 2006). This is in accordance with the results of our previous study realised with a similar protocol (Baron et al., 2009). However, self-selected speed significantly increased in downhill conditions, whereas it decreased in our previous study. The higher gradient of the running surface could be an explanation for this finding. Moreover, first and second repetitions of downhill running were performed slightly less rapidly than average running speed in our previous study $(99.9 \%$ and $99.1 \%$ of the third repetition, respectively) in accordance with the model referred to as teleoanticipation, in which physiological afferent signals are compared with antecedent experiences (Ulmer, 1996).

When analysing the result of the present study, it could be spontaneously suggested that it was prior experience of muscular pain associated with running downhill that would have led to the participants performing these first repetitions more slowly than succeeding runs. Likewise, it could explain why they performed downhill running at a lower relative speed than level-surface running (Baron et al., 2009). But in this case, the desire to stop would have been higher than during level and downhill running, while the desire to continue would have been lower. But, the opposite is observed.

Rather, we propose that the difference in the resource mobilisation between level, downhill and uphill running is the most important key that explains most of the results of this study and the process of pacing strategy.

Hence, emotional responses could be logically explained by the fact that resource mobilisation is proportional to the gradient of the running surface. Indeed, emotional responses were lower during repeated sprints performed on downhill than on the level, whereas these responses were higher during uphill running with important effect sizes.

HR responses could be also logically explained by this hypothesis. Indeed, HR was lower during repeated sprints performed on the downhill than on the level $(-2.7 \%$, approximately), whereas these responses were higher during uphill running (+6.8\%, approximately) with important effect sizes 
in accordance with our previous results (Baron et al., 2009). Of course, this is also compatible with the greater metabolic demand imposed by uphill running (di Prampero, 1986), but it is important to keep in mind that runners were asked to control the intensity as they want.

Emotional responses of each parameter were highly correlated with $\mathrm{HR}$, supporting that emotional responses are linked with physiological demand as previously suggested (Baron et al., 2009).

The most important finding of this study is that the pattern of emotional responses seems to be the same in all conditions. It corresponds to a quasimaximal level of emotional reserve at the beginning and a low level at the end of exercise. It could be supposed that during exercise, runners compare perceived exertion with the maximum effort that they are willing to mobilise for accomplishing their goals (Ekkekakis et al., 2005), i.e. more generally the level of emotional responses and the consented level in relation to the remaining time as suggested in our previous study (Baron et al., 2011).

Moreover, the results highlight that there is a linear increase in emotional parameters between the start and the end of the running repetitions in all conditions. This seems to be the most important foundation of the pattern of emotional regulation when athletes were asked to be efficient during repeated running sprints. This foundation is observed in all conditions, i.e. level, downhill and uphill running.

Then, when the gradient of running surface is changed, this pattern seems to be just translated.

According to the motivational intensity theory, effort is mobilised proportionally to the extent of difficulty (Gendolla \& Richter, 2010). Our results showed that $Y$-intercepts between the repetitions and the evolution of effort is lower during downhill than that during level and uphill running, but it is not significantly different between level and uphill running. But $Y$-intercepts between the repetitions and the evolution of the other emotional parameters are consistent with more involvement during uphill running than during level. The opposite was true during downhill repetitions. Again, it shows that the use of other emotional parameters, in addition to effort, is an interesting support to estimate the level of selfinvolvement and motivation during exercise.

The slope between most of emotional parameters and repetitions remained unchanged in all conditions. Hence, our results support that the shape of emotional pattern is not dependent on the gradient of the running surface, whereas the level of selfinvolvement is changed in relation with the subjective task difficulty. Effect of the gradient of the running surface was only observed on the slope of the capacity to realise the task and on the slope of the resources needed for the task with low effect sizes $\left(F_{2,1499}=5.6, P=0.004, \mathrm{Eta}^{2}=0.05\right.$ and $F_{2}$, ${ }_{1499}=3.2, P=0.044, \mathrm{Eta}^{2}=0.051$, respectively).

The number of repetitions or the duration certainly influences the pattern of emotional investment more significantly than the gradient of the running surface. Other protocols have to be developed in order to test the impact of other parameters of the task on the template of pacing strategies.

Finally, the link between self-selected speed and emotional responses seems to be important. This supports the fact that emotional parameters play an important role in the control of self-selected speed (Baron et al., 2011). This conscious control could not be ignored in the pacing process. Indeed, an important finding of this study is that all emotional parameters were correlated with self-selected speed in all running conditions except for pleasure and desire to continue during downhill repetitions. This is in accordance with the hypothesis that the importance of the non-conscious part of control is perhaps reinforced in order to preserve the organism when physiological damage is imposed (Baron et al., 2009). More investigations have to be designed in order to confirm this hypothesis and the relative importance of conscious vs. non-conscious part of control.

In this study, specific emotional parameters (i.e. the effort, the pleasure, the $\mathrm{AB}$, the desire to stop, the desire to continue, the resources needed for the task and the capacity to realise the task) have been used to analyse the emotional regulation. This study shows that these parameters seem relevant in order to analyse this process.

\section{Conclusion}

Our results show that emotional responses were controlled during intermittent exercise in order that effort could be maintained until the end for all running surfaces (level, downhill and uphill running) (Baron et al., 2011).

Hence, while average values of emotional parameters were significantly different on each condition, the gradient of the running surface did not influence the pattern of emotional responses. The strategy corresponds to a quasi-maximal level of emotional reserve at the beginning and to a low level at the end of exercise. It could be supposed that during exercise, runners compare perceived exertion with the maximum effort they are willing to mobilise for accomplishing their goals (Ekkekakis et al., 2005), i.e. more generally the level of emotional responses and the consented level in relation to the remaining time as suggested in our previous study (Baron et al., 2011).

The pattern seems to be just translated in relation with the gradient of the running surface. It is 
probably linked to the subjective difficulty of the task as proposed by the motivational intensity theory (Gendolla \& Richter, 2010).

Other studies have to be designed in order to confirm that this model is valid for other experimental conditions.

\section{References}

Baron, B., Deruelle, F., Moullan, F., Dalleau, G., Verkindt, C., \& Noakes, T. D. (2009). The eccentric muscle loading influences the pacing strategies during repeated downhill sprint intervals. European fournal of Applied Physiology, 105(5), 749-757. doi:10.1007/s00421-008-0957-6

Baron, B., Moullan, F., Deruelle, F., \& Noakes, T. D. (2011). The role of emotions on pacing strategies and performance in middle and long duration sport events. British fournal of Sports Medicine, 45(6), 511-517.

Baron, B., Noakes, T. D., Dekerle, J., Moullan, F., Robin, S., Matran, R., \& Pelayo, P. (2008). Why does exercise terminate at the maximal lactate steady state intensity? British fournal of Sports Medicine, 42(10), 528-533.

Beedie, C. J., \& Lane, A. M. (2012). The role of glucose in selfcontrol: Another look at the evidence and an alternative conceptualization. Personality and Social Psychology Review, 16 (2), 143-153.

Borg, G., Ljunggren, G., \& Ceci, R. (1985). The increase of perceived exertion, aches and pain in the legs, heart rate and blood lactate during exercise on a bicycle ergometer. European Fournal of Applied Physiology and Occupational Physiology, 54(4), 343-349.

Damasio, A. R. (1994). Descartes' error: Emotion reason, and the human brain. New York, NY: Avon Books.

Damasio, A. R. (1999). The feeling of what happens: Body and emotion in the making of consciousness. New York, NY: Harcourt Brace.

de Koning, J. J., Bobbert, M. F., \& Foster, C. (1999). Determination of optimal pacing strategy in track cycling with an energy flow model. Fournal of Science and Medicine in Sport, 2 (3), 266-277.

di Prampero, P. E. (1986). The energy cost of human locomotion on land and in water. International fournal of Sports Medicine, 7 (2), 55-72.

Ekkekakis, P., Hall, E. E., \& Petruzzello, S. J. (2005). Variation and homogeneity in affective responses to physical activity of varying intensities: An alternative perspective on dose-response based on evolutionary considerations. Fournal of Sports Sciences, 23(5), 477-500.

Foster, C., De Koning, J. J., Hettinga, F., Lampen, J., Dodge, C., $\&$ Bobbert, M. (2004). Effect of competitive distance on energy expenditure during simulated competition. International fournal of Sports Medicine, 25(3), 198-204.

Foster, C., De Koning, J. J., Hettinga, F., Lampen, J., La Clair, K. L., Dodge, C., ... Porcari, J. P. (2003). Pattern of energy expenditure during simulated competition. Medicine $\mathbb{E}$ Science in Sports E Exercise, 35(5), 826-831.

Foster, C., Schrager, M., Snyder, A. C., \& Thompson, N. N. (1994). Pacing strategy and athletic performance. Sports Medicine, 17(2), 77-85.

Foster, C., Snyder, A. C., Thompson, N. N., Green, M. A., Foley, M., \& Schrager, M. (1993). Effect of pacing strategy on cycle time trial performance. Medicine $\mathbb{E}$ Science in Sports $\mathcal{E}$ Exercise, 25(3), 383-388.
Gendolla, G. H. E., \& Richter, M. (2010). Effort mobilization when the self is involved: Some lessons from the cardiovascular system. Review of General Psychology, 14(3), 212-226.

Herbert, B. M., Pollatos, O., \& Schandry, R. (2007). Interoceptive sensitivity and emotion processing: An eeg study. International fournal of Psychophysiology, 65(3), 214-227.

Herbert, B. M., Ulbrich, P., \& Schandry, R. (2007). Interoceptive sensitivity and physical effort: Implications for the self-control of physical load in everyday life. Psychophysiology, 44(2), 194-202.

Hettinga, F. J., De Koning, J. J., Broersen, F. T., Van Geffen, P., \& Foster, C. (2006). Pacing strategy and the occurrence of fatigue in 4000-m cycling time trials. Medicine $\mathcal{E}$ Science in Sports E Exercise, 38(8), 1484-1491.

Hettinga, F. J., De Koning, J. J., Meijer, E., Teunissen, L., \& Foster, C. (2007). Biodynamics. effect of pacing strategy on energy expenditure during a $1500-\mathrm{m}$ cycling time trial. Medicine $\mathcal{E}$ Science in Sports \& Exercise, 39(12), 2212-2218.

James, W. (1994). The physical basis of emotion. Psychological Review, 101(2), 205-210.

Lambert, E. V., St Clair Gibson, A., \& Noakes, T. D. (2005). Complex systems model of fatigue: Integrative homoeostatic control of peripheral physiological systems during exercise in humans. British Fournal of Sports Medicine, 39(1), 52-62.

Lane, A. M., Wilson, M. G., Whyte, G. P., \& Shave, R. (2011). Physiological correlates of emotion-regulation during prolonged cycling performance. Applied Psychophysiology and Biofeedback, 36(3), 181-184.

Mizrahi, J., Verbitsky, O., \& Isakov, E. (2000). Shock accelerations and attenuation in downhill and level running. Clinical Biomechanics, 15(1), 15-20.

Noakes, T. D., St Clair Gibson, A., \& Lambert, E. V. (2004). From catastrophe to complexity: A novel model of integrative central neural regulation of effort and fatigue during exercise in humans. British fournal of Sports Medicine, 38(4), 511-514.

Noakes, T. D., St Clair Gibson, A., \& Lambert, E. V. (2005). From catastrophe to complexity: A novel model of integrative central neural regulation of effort and fatigue during exercise in humans: Summary and conclusions. British fournal of Sports Medicine, 39(2), 120-124.

Peake, J., Nosaka, K., \& Suzuki, K. (2005). Characterization of inflammatory responses to eccentric exercise in humans. Exercise Immunology Review, 11, 64-85.

Seo, M. G., Barrett, L. F., \& Bartunek, J. M. (2004). The role of affective experience in work motivation. Academy of Management Review, 29(3), 423-439.

St Clair Gibson, A., Baden, D. A., Lambert, M. I., Lambert, E. V., Harley, Y. X. R., Hampson, D., ... Noakes, T. D. (2003). The conscious perception of the sensation of fatigue. Sports Medicine, 33(3), 167-176.

St Clair Gibson, A., \& Foster, C. (2007). The role of self-talk in the awareness of physiological state and physical performance. Sports Medicine, 37(12), 1029-1044.

St Clair Gibson, A., Lambert, E. V., Rauch, L. H. G., Tucker, R., Baden, D. A., Foster, C., \& Noakes, T. D. (2006). The role of information processing between the brain and peripheral physiological systems in pacing and perception of effort. Sports Medicine, 36(8), 705-722.

St Clair Gibson, A., Lambert, M. I., \& Noakes, T. D. (2001). Neural control of force output during maximal and submaximal exercise. Sports Medicine, 31(9), 637-650.

Ulmer, H. V. (1996). Concept of an extracellular regulation of muscular metabolic rate during heavy exercise in humans by psychophysiological feedback. Experientia, 52(5), 416-420. 